\title{
Rat Spermatogenesis Damage in Intermittent Hypobaric Hypoxia and the Protective Role of Melatonin. II: Testicular Parameters
}

\author{
Daño de la Espermatogénesis en Rata en la Hipoxia Hipobárica Intermitente \\ y Rol Protector de la Melatonina. II: Parámetros Testiculares
}

"Eduardo Bustos-Obregón; *** Rodrigo Castro-Sánchez; ${ }^{* * *}$ Benito Ramos-González \& ${ }^{* * * *}$ Leandro Torres-Díaz

BUSTOS-OBREGÓN, E.; CASTRO-SÁNCHEZ; RAMOS-GONZÁLEZ, B. \& TORRES-DÍAZ, L. Rat spermatogenesis damage in intermittent hypobaric hypoxia and the protective role of melatonin. II: testicular parameters. Int. J. Morphol., 28(2):537-547, 2010.

SUMMARY: At present it is not clear if male fertility is affected by intermittent hypobaric hypoxia (IHH). This is an important issue since a large human population works over 3000 masl. This study analyzes testicular changes in adult Sprague Dawley rats after five cycles of IHH ( 7 day exposure to 4200 masl in a hypobaric chamber / 7 day at 500 masl). The animals were separated into groups of 8 , one group was exposed to hypoxia (7 days), and the others to IHH for one to five cycles. Controls (500 masl) were examined at the beginning and at the end of the 70 experimental days. A duplicate set of rats treated with melatonin (supposedly protecting from hypoxia) was also examined, as were their controls, injected with 0,03\% ethanol (melatonin solvent).Immunohistochemical and histometric analysis of testicular tissue were performed. Damage caused by IHH increases with time. Morphometry reveals an increase in tubular and luminal diameters and a reduction in epithelial height. Inmunohistochemistry for HIF-1alpha shows an increase with time, however the opposite happens with HSP-70. Spermatogenic cells submitted to comet assay present an increase of $(+)$ cells. Melatonin counteracts all this damage, possibly due to its high efficiency as a reactive oxygen species scavenger. In conclusion, IHH exposure damages male reproductive function.

KEY WORDS: Spermatogenesis, intermittent hypobaric hypoxia, melatonin protection.

\section{INTRODUCTION}

As altitude increases, both the barometric pressure and the partially inspired oxygen pressure decreases and generates hypoxia (Chinn \& Hannon, 1970; Gamboa, 1998). It was considered that exposure to hypobaric hypoxia produced a great physiological stress inducing cellular responses that result in deleterious effects at the level of certain tissues (Sarada et al., 2002). Reports provided by our research has shown the action of these harmful effects on reproductive parameters in the testis and epididymis (Bustos-Obregón \& Celis, 1982; Farias et al., 2005). The mechanism of action -implicated in fertility reduction- has not been accurately established, reason for which the problem needs to be further reviewed and studied, particularly for cases of intermittent hypoxia, which is the most common form of human exposure to hypoxia in mining activities in the north of Chile.
Moreover, a recent publication by Siqués \& Brito (2001) refers to intermittent high altitude labors as a new epidemiological situation of global health concern.

The knowledge about the causes of damage produced by hypoxia has greatly increased, and has been attributed mainly to the generation of reactive oxygen species (ROS) and nitrogen resulting in the alteration of certain cellular processes (Magalhaes et al., 2004; Magalhaes et al., 2004b; Bailey et al., 2001 Moller et al., 2001) leading to oxidative stress (El-Missiry, 2000). The plasma membrane is one of the places where cell damage by ROS can be induced. Its constituent polyunsaturated fatty acids may undergo lipid peroxidation, which leads to degenerative cell alterations (Bhardwaj et al., 2000; El-Sokkary et al., 2003). The damage in the integrity of the plasma membrane will increase its

Laboratory of Biology of Reproduction, Program of Anatomy and Developmental Biology, ICBM, Medical School, Universidad de Chile.

** School of Veterinary Medicine, Universidad Iberoamericana de Ciencias y Tecnología, UNICIT, Santiago, Chile.

**** Andrology Laboratory, Pathology Department, Medical School, UANL, Monterrey, México.

${ }^{* * * *}$ Laboratory of Histology and Reproduction, Faculty of Sciences, University de Playa Ancha, Valparaíso Chile. 
permeability, leading to the inactivation of certain enzymatic systems, structural damage to the DNA, and even to cell death (Koksal et al., 2003; Engel et al., 1999).

It is well known that hypoxia exerts an inhibiting effect on all dividing cell populations (Kim and Han, 1969; Check et al., 1969) so that the cell populations involved in the gametogenic process might be susceptible to this condition.

It has been suggested that the main generator of reactive oxygen species and hence lipid peroxidation is themitochondria (Behn, et al., 2007). It has been shown that testicular tissue and sperm are damaged by lipid peroxidation (Othman et al., 2001). The action of certain antioxidant molecules in most tissues, such as glutathione and superoxide dismutase (SOD) is known. The latter (SOD) have a depressed expression in skeletal muscle mitochondria of rats exposed to hypobaric hypoxia (4000 masl; Radak et al., 1994). Under normal physiological conditions, there is a balance between pro-oxidant molecules and antioxidants (Engel et al., 1999). It is known that the testis is equipped with antioxidant defense molecules, their concentrations are relatively low compared with liver levels (Bauche et al., 1994) leaving the gonad vulnerable to damage. When the formation of ROS surpasses the antioxidant capacity of the intracellular protective mechanisms, the probability of oxidative damage on important cell biomolecules (such as proteins, carbohydrates, lipids and nucleic acids) increases (Pande \& Flora, 2002; El-Missiry, 2000; Ercal et al., 1996). An increase in the incidence of oligospermia has been reported in patients who also present an increase in ROS levels in seminal plasma (Whittington et al., 1999). In addition, ROS can induce damage in the cell DNA and apoptosis in spermatozoa (Agarwal \& Said, 2005). Therefore, supplementing with exogenous antioxidant agents could be of great relevance for the prevention and treatment of oxidative damage in testis and spermatozoa.

Hypoxia Inducible Factor 1 alpha (HIF-1). Factor 1 (HIF1) is a transcriptional activator. The nature of the oxygen sensor that causes the greater expression of HIF-1 is still unknown. Besides regulating the erythropoietin gene, HIF1 activates the transcription of several other genes (approximately 70) in a coordinated manner, and these codified proteins help the cells to respond to hypoxia (Galanis et al., 2008; Lodish et al., 2005). Recent studies indicate that hypoxia stimulates the release of reactive oxygen species (ROS) from mitochondria, regulating the transcriptional response generated in conditions of hypoxia, which in turn can induce physiological alterations leading to oxidative stress. (Agarwal \& Said, 2005; Hsu et al., 1997; Ping-Chui et al., 1998, Golden et al., 1999; El-Missiry, 2000).
Heat Shock Proteins (HSP). Heat shock proteins (HSP) belong to a family that is constitutively expressed in all prokaryotic and eukaryotic cells. Against certain environmental aggressions, most organisms react with a mechanism of cell defense that involves the over expression of these proteins and the induction of other members of the HSP family which are not constitutive. When the stresscausing factor is eliminated, cells recover their steady metabolism. However, if the stress increases and the protective function of HSPs is surpassed, their production stops and apoptosis or programmed cell death initiates (Samali \& Cotter, 1996).

Melatonin. Melatonin or N-acetyl-5-methoxytryptamine is a molecular and physiological regulator and is mainly synthesized in the pineal gland of vertebrates (Reiter et al., 2001). Serum concentrations of melatonin show a circadian rhythm, with their highest levels during the dark phase (Reiter, 1991). Melatonin is a direct potent free radical scavenger and antioxidant (Tan et al., 1993). Numerous reports have documented the protective action of melatonin in several models of cell oxidative stress (Hiro-Aki \& Hai-Wang, 1996). Melatonin has been shown to prevents the DNA, lipid and proteins from oxidative damage, which is performed by endogenous and exogenous toxins (Vijayalaxmi et al., 1998; Anwar et al., 1998; Lena \& Subramanian, 2003; El-Missiry, 2000; Kim et al., 1998). More than 1000 publications have confirmed the ability of melatonin and its metabolites to reduce oxidative stress in vivo (Reiter et al., 2001; Tan et al., 2003; Hardeland, 2005). Due to its lipophilic and hydrophilic properties (that allow it to cross cell membranes easily) melatonin has the capacity to provide antioxidant protection to most subcellular compartments (Lena \& Subramanian, 2003).

The antioxidant function of Melatonin has been associated to its capacity to scavenge reactive oxygen/ nitrogen species (ROS/RNS) (Hardeland, 2005). with a better antioxidant effect than glutathione against the highly toxic hydroxyl radical; it also has more effective antioxidant properties than tocopherols (El-Missiry, 2000). Many studies have shown that melatonin is more effective protecting against oxidative damage than other antioxidants, including vitamin E, glutathione and mannitol (Reiter et al., 2005; Reiter et al., 2003; Zhao et al., 2003; Patil et al., 2009). Melatonin receptors have been identified in both female and male gonads (Woo et al., 2001, Frungieri et al., 2005).In addition, it can cross morpho-physiological barriers such as the blood-testis barrier, thus protecting most cells from oxidative damage (Kim et al., 1998).

It has been suggested that melatonin could be used clinically against a variety of toxic agents that provoke damage as a consequence of the action of free radicals (Kim 
et al., 1998) because Melatonin is highly specific against lipid peroxidation, a phenomenon that increases remarkably as a cell response to hypoxia.

The present study analyzes the spermatogenic damage, denoted by HIF-1 alpha activation and HSP70 response to metabolic deterioration, as well as the role of ROS in intermittent hypobaric hypoxia and the protective function of the antioxidant melatonin, in an effort to characterize and counteract the reproductive deleterious effects of hypoxia in the rat testis.

\section{MATERIAL AND METHOD}

For this study, 144 healthy, sexually mature (2-3 months old) male Sprague Dawley rats were obtained from the animal room of the School of Medicine, University of Chile. They were kept under a 12:12 hs light-dark regime at $22 \pm 2{ }^{\circ} \mathrm{C}$ and fed with pelleted food and water ad libitum. Rats were separated into 18 groups of 8 individuals each. The experimental scheme considered a two-step design, with one incorporating melatonin treatment in the drinking water $(10 \mathrm{mg} / \mathrm{kg})$. The following groups were included: Controls 1 and 2, maintained in conditions of normoxia (Santiago de Chile city, barometric pressure (PB) of $710 \mathrm{~mm} \mathrm{Hg}, 540$ meters above sea level (masl), PO2=148,6 mm Hg) and sacrificed at the beginning and at the end of the experiment, respectively; and Groups 1, 2, 3, 4 and 5, exposed to intermittent hypoxia ( $\mathrm{IHH}$, simulating 4200 masl PB and PO2 conditions) in cycles of $7 \mathrm{~d}: 7 \mathrm{~d}$ hypoxia/normoxia $(1$ cycle $=$ 14 days) simulated by a hypobaric chamber. The groups were exposed to "n" cycles, with n determined according to the name of the respective group. One extra group was exposed only to 7 days of IHH, without an alternating period of normoxia. For the melatonin treatment, 2 control groups consuming ethanol $0,03 \%$ (vehicle for melatonin) in the drinking water were added. (see chart in Table I).
Once the experimentation intervals were completed for each group, a blood sample was obtained from each individual and the percentage of microhematocrit and reticulocytes was calculated in a blood smear dyed with cresyl blue and read under a light microscope (400X) until completing 100 cells.

Rats were sacrificed according to the protocol accepted by the Ethics Committee of the School of Medicine, University of Chile. Testicles were excised post-mortem and the following analyses were performed: Comet assay (left testis; Ostlingand Johanson, 1994).

Right testis were fixed in aqueous Bouin solution and paraffin-included to perform routine histological techniques, morphometrical analysis and immunohistochemistry. For each individual, morphometrical measurements of 200 cross-sectioned seminiferous tubules were taken to determine the height of seminiferous tubules, and tubular and luminal diameters. The measurements were performed on the basis of digitalized microphotographs obtained with a microscope-coupled digital camera and using the software "Image Tool 3.0".

Cross-sections of seminiferous tubules were mounted on xylane-coated slides and submitted to immunohistochemical techniques for HIF-1 alpha, using the policlonal antibody HIF-1 alpha (H-206, Santa Cruz Biotechnology 10790, 1:50) and for HSP-70, using the monoclonal antibody HSP-70 (W27, Santa Cruz Biotechnology 24, 1:20). Antigen recovery was performed in citrate buffer, $\mathrm{pH}$ 6, and developed with diaminobenzidine (DAB).

Means and standard deviations were calculated for every parameter and an analysis of variance (ANOVA) was performed using the F test. The F value was calculated with the statistical software Stata 8.0 and statistical significance was established when $\mathrm{p}<0.05$.

Table I. Sinoptic chart of experimental protocol. Experimental design. 1 cycle $=7$ days hypoxia $/ 7$ days normoxia. IHH:Intermittent hypobaric hypoxia (simulating 4200 masl). Day 0 denotes the beginning of exposure.

\begin{tabular}{lcc}
\hline Group & $\begin{array}{c}\text { Cycles IHH }(1 \text { cycle }=7 \text { days } \\
\text { hypoxia } / 7 \text { days normoxia) }\end{array}$ & $\begin{array}{c}\text { Days at the moment of the sacrifice } \\
\text { (day 0= ex perience started) }\end{array}$ \\
\hline Control 1 & 0 & 0 \\
Control 2 & 0 & 70 \\
7 days & 7 days hypoxia & 7 \\
1 cycle & 1 & 14 \\
2 cycle & 2 & 28 \\
3 cycle & 3 & 42 \\
4 cycle & 4 & 56 \\
5 cycle & 5 & 70 \\
\hline
\end{tabular}




\section{RESULTS}

Blood analysis. Hematocrit values increased significantly after 7 days of exposure to hypoxia, returning to normality soon after cessation of the treatment (Table II). Reticulocyte percentages also increased progressively along with duration of exposure to hypoxia, reaching a maximum value on the second cycle and then declining to values similar to the control group (Table II). Melatonin attenuates these variations, with values similar among treated and control groups when used concomitantly with hypoxia. Generally speaking, the behavior of blood variables express an expected physiological response against hypobaric intermittent hypoxia.

Comet Assay (Fig. 1). It has been observed, that the higher the number of cycles of exposure to hypoxia, the more cells present damaged chromatin (Comet percentage increase), being statistically significant for cycles 3, 4 and 5 . IHH mainly damages the nuclei of epididymal sperm and consequently correlates with sperm head anomalies and positive Comet frequency. Such an increase is minor, but it maintains its tendency in groups that received melatonin in drinking water becoming significant in groups 3, 4 and 5 . The percentage of positive Comet spermatocytes turned out to be significantly lower in groups 4 and 5 of melatoninconsuming rats when compared to those that did not consume melatonin. The overall rate of teratozoospermia follows the same pattern than that of the Comet assay results.

Morphometrical Variables. The seminiferous tubule diameter tended to increase, reaching values above that of the control group after the fourth and fifth IHH cycle; the luminal diameter increased considerably in the same groups. Meanwhile, the height of the seminiferous epithelium was significantly reduced only in the second cycle (Table III).

Table II. Blood analysis. Hematocrit after IHH. Tends to increase progressively in the groups with and without melatonin. In the group 7 days there is a marked increase only without melatonin. Percentage of reticulocytes after IHH. Melatonin avoids partially the peaks found in goups without melatonin. reticulocytes tend to increase with more cycles and then (3rd cycle) lowers to control like values.

\begin{tabular}{lcccccc}
\hline & \multicolumn{3}{c}{ Hematocrit } & \multicolumn{3}{c}{ Retyculocyte \% } \\
\hline Group & $\begin{array}{c}\text { Without } \\
\text { melatonin }\end{array}$ & Melatonin & Ethanol & $\begin{array}{c}\text { Without } \\
\text { melatonin }\end{array}$ & Melatonin & Ethanol \\
\hline Control 1 & 35.4 & 43.6 & 43.9 & 2.1 & 2.3 & 1.8 \\
Control 2 & 46.0 & 48.2 & 44.2 & 1.6 & 1.3 & 1.8 \\
7 days & $46.0 *$ & 39.0 & - & 2.9 & 3.3 & - \\
1 cycle & 37.7 & 43.6 & - & 4.1 & 3.1 & - \\
2 cycle & 39.5 & 45.6 & - & $5.1 *$ & 3.4 & - \\
3 cycle & 43.1 & 47.2 & - & 3.6 & 2.5 & - \\
4 cycle & 44.0 & 44.2 & - & 3.0 & 2.2 & - \\
5 cycle & $46.6 *$ & 47.2 & - & & \\
\hline$*$ Experimental v/s control $(\mathrm{p}<0.05) ; * *$ Melatonin $(+)$ v/s melatonin $(-)$ in the same cycle $(\mathrm{p}<0.05)$.
\end{tabular}

Table III. Morphometrical variables. The tubular diameter increases at longer time intervals (4th and 5th cycles). Diameters tend to be smaller with melatonin. The luminal diameter increases significantly by the 4th and 5 th cycles in the groups without melatonin. In the second cycle there is a marked decrease in the epithelial height in animals without melatonin, whereas melatonin avoided this change.

\begin{tabular}{|c|c|c|c|c|c|c|c|c|c|}
\hline \multirow[b]{2}{*}{ Group } & \multicolumn{3}{|c|}{ Tubular diameter $(\mu \mathrm{m})$} & \multicolumn{3}{|c|}{ Luminal diameter $(\mu \mathrm{m})$} & \multicolumn{3}{|c|}{ Epithelial height $(\mu \mathrm{m})$} \\
\hline & $\begin{array}{l}\text { Without } \\
\text { melatonin }\end{array}$ & Melatonin & Ethanol & $\begin{array}{l}\text { Without } \\
\text { melatonin }\end{array}$ & Melatonin & Ethanol & $\begin{array}{l}\text { Without } \\
\text { melatonin }\end{array}$ & Melatonin & Ethanol \\
\hline Control 1 & 258.02 & 255.85 & 271.53 & 125.45 & 123.81 & 122.29 & 71.61 & 68.43 & 77.83 \\
\hline Control 2 & 256.93 & 259.22 & 263.35 & 136.61 & 145.69 & 150.47 & 71.65 & 60.24 & 60.76 \\
\hline 7 days & 254.21 & 238.72 & . & 141.66 & 128.27 & - & 61.02 & 65.10 & - \\
\hline 1 cycle & 260.46 & 244.45 & - & 134.09 & 133.03 & - & 70.53 & 70.85 & - \\
\hline 2 cycle & 239.54 & 235.40 & - & 132.20 & 130.69 & - & $55.94^{* *}$ & 65.17 & - \\
\hline 3 cycle & 262.61 & 236.95 & - & 126.89 & 114.74 & - & 67.08 & 68.22 & - \\
\hline 4 cycle & $282.79^{* *}$ & $244.40^{*}$ & - & $167.67^{* *}$ & $121.83^{*}$ & - & 65.66 & 66.07 & - \\
\hline 5 cycle & $302.03^{* *}$ & $267.65^{*}$ & - & $188.16^{* *}$ & $147.40^{*}$ & - & 61.51 & 63.80 & - \\
\hline
\end{tabular}

$*=$ Experimental v/s control $(\mathrm{p}<0.05) ; * *=$ melatonin $(+) \mathrm{v} / \mathrm{s}$ melatonin $(-)$ in the same cycle $(\mathrm{p}<0.05)$. 
Progressive vacuolization was noticed when the number of exposure intervals increased. Damage induced by IHH -as expressed by the tendencies towards an increase in tubular diameter and reduction in the luminal diameter and epithelium height- may be reduced by melatonin; a similar phenomenon occurring with progressive vacuolization of the seminiferous epithelium is observed. (Fig. 2)

The antioxidant characteristic of melatonin and its protective role against tissue damage caused by exposure to IHH, might mean that reactive oxygen species actively participates in these lesions.

Immunohistochemical Variables. The expression of HIF1 alpha (expressed in conditions of hypoxia and promoter of angiogenesis) and HSP-70 (expressed in conditions of heat shock) were used as indicators to estimate testicular damage in $5 \mu \mathrm{m}$ sections of rats testis submitted to IHH.
HIF-1 alpha: (Table IV, Fig. 3). The percentage of HIF-1 alpha positive tubules and interstitium, increased when the number of exposure cycles increased, with results significantly different to that of the control groups from the third cycle onwards. Melatonin decreased the seminiferous tubular expressions of HIF-1 alpha, keeping these values close to the controls. This situation becomes significant from the third cycle onwards, compared to animals not treated with melatonin. In the interstitium, melatonin seems not to modify the expressions of HIF-1 alpha.

HSP-70 (Table V). It shows the maximum number of positive tubules after acute exposure (7 days) and slightly smaller values after longer intervals (70 days), implying a two-phase response that deserves further studies. There was no clear expression of HSP-70 in the intertitium. Melatonin does not modify the expressions of HSP-70, neither in the seminiferous epithelium nor in the interstitium.

Table IV. Immunohistochemical variables (HIF-1 alpha). By the 3rd cycle onwards in the animals without melatonin a larger number of tubules are marked, whereas this number decreases in melatonine treated animals. The percentage of HIF-1 alpha expression in the interstice is higher only in the 3rd and 4th cycle in animals without melatonin.

\begin{tabular}{lcccccc}
\hline & \multicolumn{2}{c}{ Percentage of HIF $(+)$ tubule } & \multicolumn{2}{c}{ Percentage of HIF $(+)$ interstitium } \\
\hline Group & $\begin{array}{c}\text { Without } \\
\text { melatonin }\end{array}$ & Melatonin & Ethanol & $\begin{array}{c}\text { Without } \\
\text { melatonin }\end{array}$ & Melatonin & Ethanol \\
\hline Control 1 & 49.97 & 47.28 & 45.07 & 8.33 & 10.67 & 8.33 \\
Control 2 & 48.84 & 45.17 & 48.88 & 10.00 & 11.33 & 9.27 \\
7 days & 51.56 & 49.00 & - & 6.67 & 8.67 & - \\
1 cycle & 61.03 & 58.07 & - & 12.00 & 8.33 & - \\
2 cycle & 50.28 & 49.50 & - & 13.33 & 15.00 & - \\
3 cycle & $75.41^{* *}$ & $61.50^{*}$ & - & $20.00^{*}$ & 16.67 & - \\
4 cycle & $85.26^{* *}$ & 58.17 & - & $18.33^{*}$ & 13.33 & - \\
5 cycle & $100.00^{* *}$ & 66.33 & - & 8.00 & 11.67 & - \\
\hline
\end{tabular}

$*=$ Experimental v/s control $(\mathrm{p}<0.05) ; * *=$ melatonin $(+) \mathrm{v} / \mathrm{s}$ melatonin $(-)$ in the same cycle $(\mathrm{p}<0.05)$

Table V. Immunohistochemical variables (HSP-70). The percentage of tubules with HSP-70 expression is higher by 5 cycles and similar to acute seven days exposure. HSP-70 expression in the interstice does not show any relevant response neither with hypoxia nor with melatonin.

\begin{tabular}{lcccccc}
\hline & \multicolumn{3}{c}{ Percentage of HSP-70 $(+)$ tubule } & \multicolumn{3}{c}{ Percentage of HSP-70 (+) inter stitium } \\
\hline Group & $\begin{array}{c}\text { Without } \\
\text { melatonin }\end{array}$ & Melatonin & Ethanol & $\begin{array}{c}\text { Without } \\
\text { melatonin }\end{array}$ & Melatonin & Ethanol \\
& 30.95 & 31.27 & 19.87 & 10.00 & 13.33 & 10.00 \\
Control 1 & 33.47 & 27.18 & 16.30 & 13.33 & 11.67 & 8.33 \\
Control 2 & 63.49 & 60.73 & - & 8.33 & 7.00 & - \\
7 days & 15.39 & 14.50 & - & 16.67 & 16.00 & - \\
1 cycle & 17.56 & 20.00 & - & 13.33 & 11.00 & - \\
2 cycle & 20.35 & 19.04 & - & 16.67 & 13.33 & - \\
3 cycle & 17.22 & 16.58 & - & 16.67 & 16.67 & - \\
4 cycle & 50.02 & 47.46 & - & 10.00 & 13.33 & - \\
5 cycle & & & & & & \\
\hline
\end{tabular}


BUSTOS-OBREGÓN, E.; CASTRO-SÁNCHEZ; RAMOS-GONZÁLEZ, B. \& TORRES-DÍAZ, L. Rat spermatogenesis damage in intermittent hypobaric hypoxia and the protective role of melatonin. II: testicular parameters. Int. J. Morphol., 28(2):537-547, 2010.

\section{SPERMATOCYTE COMET ASSAY (+) (\%)}

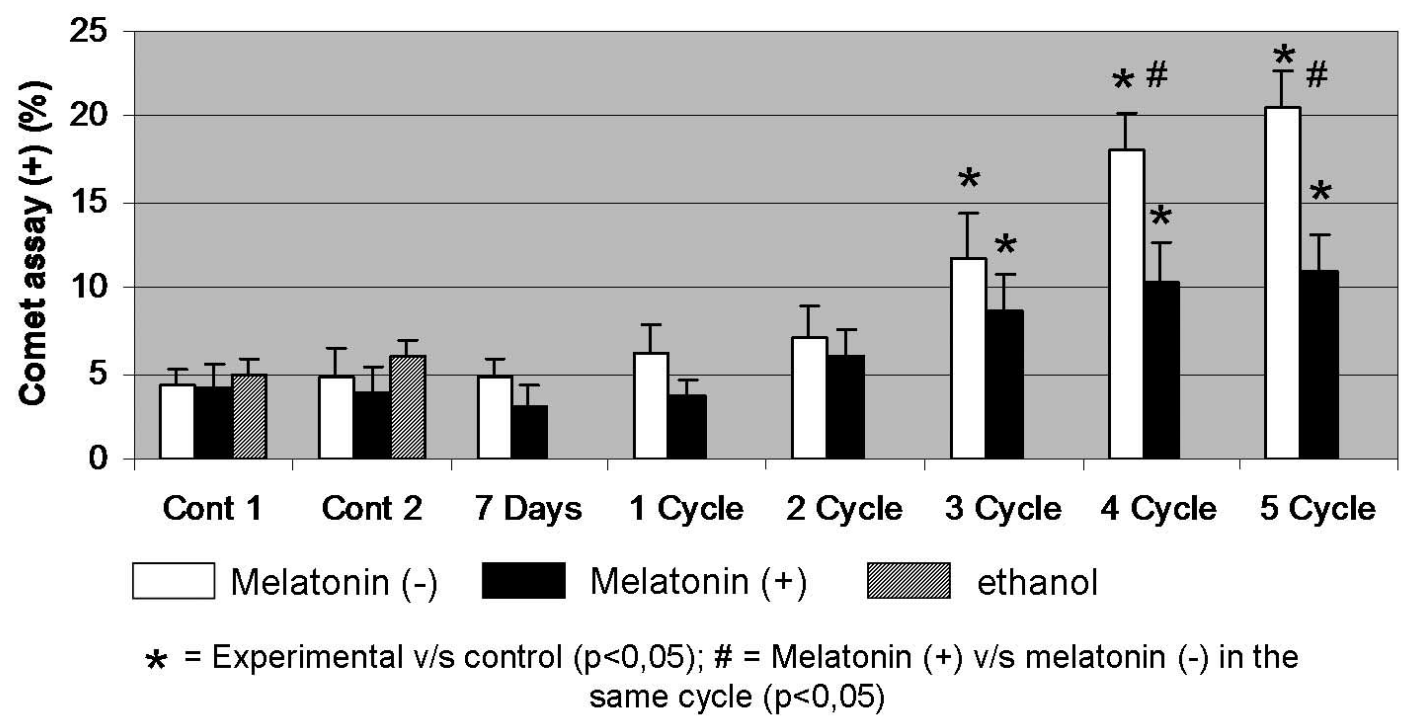

Fig. 1. Percentage of comet (+) test with and without melatonin tends to increase progressively, being significant by the 3rd cycle onward.
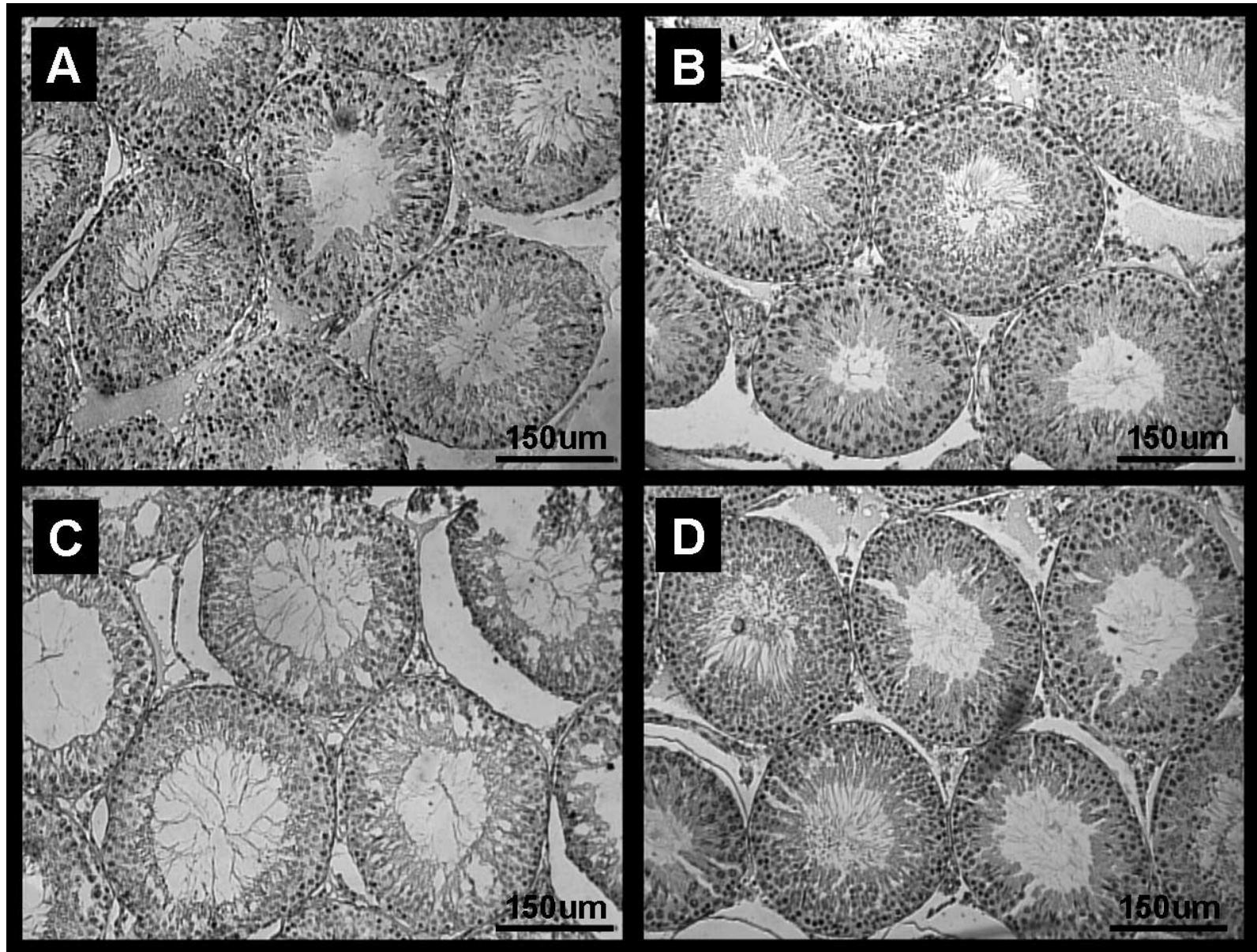

Fig. 2. Rat testicular sections. (A) Control without melatonin. (B) Control with melatonin. (C) 5 cycles of IHH without melatonin.

(D) 5 cycles of IHH with melatonin. In comparison with controls, in groups $\mathrm{C}$ and $\mathrm{D}$ there is decrease in height, vacuolization of seminiferous epithelium and enlargement of tubular lumen. Melatonin partially prevents all these changes. 

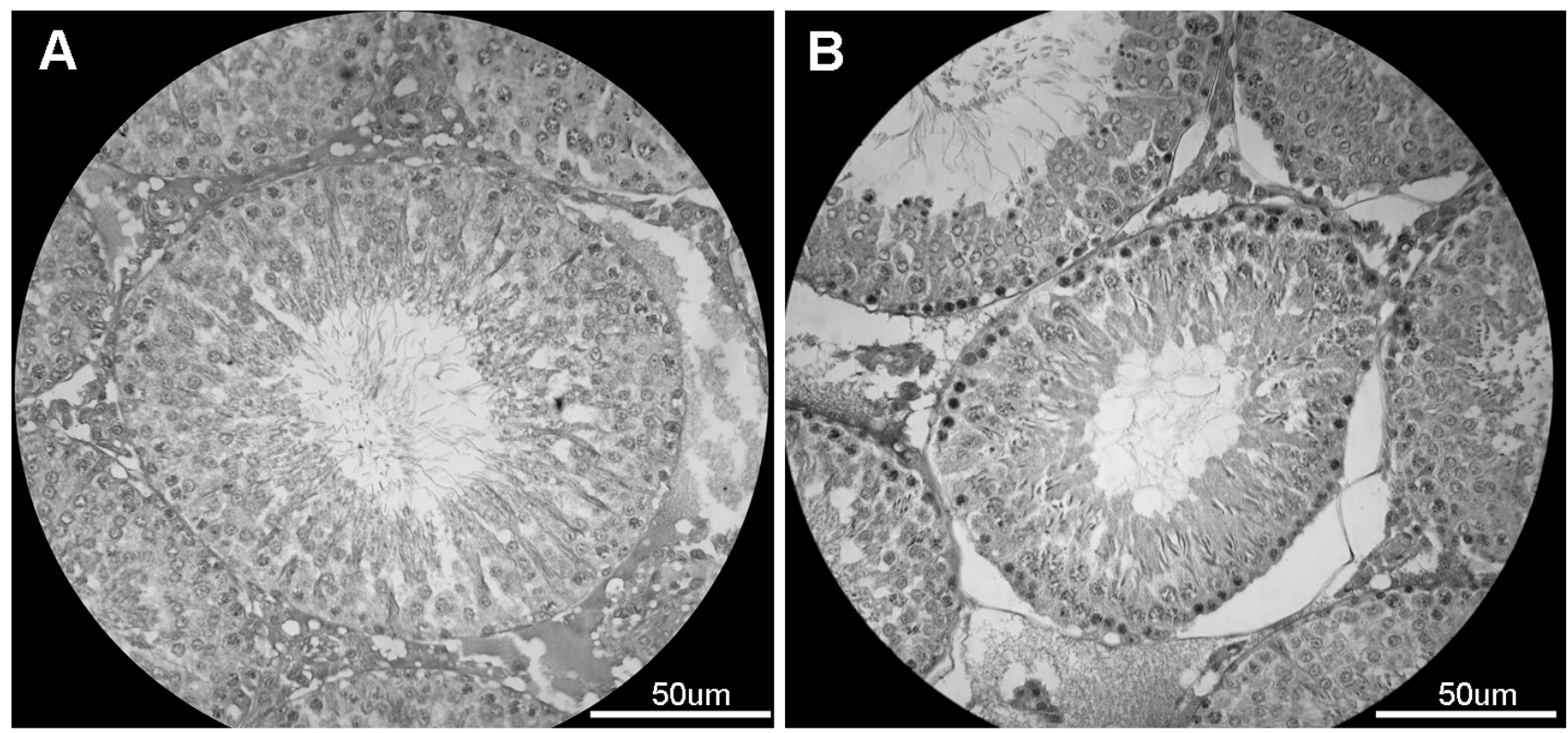

Fig. 3. Inmunohistochemistry for HIF-1 alpha. Control seminiferous tubules (A). Exposed for 5 cycles of IHH (B). Positive mark on preleptotene espermatocytes $(\mathrm{bar}=50 \mathrm{um})$.

\section{DISCUSSION}

Hypobaric hypoxia is responsible for alterations in the reproductive function, both in humans and animals (Bustos-Obregón \& Celis; Bustos-Obregón et al., 2005, 2006; Farias et al., 2005). Some authors associated fertility problems to work on shift systems. This phenomenon has been dealt with in numerous studies (Xu et al., 1994; Bisanti et al., 1996; Costa, 1996; Kogi, 1996; Monk et al., 1996; Nurminem, 1998; Scout, 2000; Zhu et al., 2003; Harma, 2006; Berger \& Hobbs 2006), showing that shift work is a condition of biological stress, mental and social situation that could jeopardize the health, wellbeing and work performance generating adverse outcomes of pregnancy such as spontaneous abortions and low birth weight. Thus the shift system is an important confounding factor when studying the relationship between fertility and altitude, as one may have a synergistic effect or mask the relationship.

Although reductions in reproductive parameters have already been associated with the exposure to hypoxic environments (Bustos-Obregón et al., 2006;), there is uncertainty regarding the mechanism of action in the case of intermittent exposure to this factor in a similar situation to that faced by mineworkers at high altitudes.

The proposed experimental model helps, in part, to determine the ways in which this noxa negatively affects the male factor, determining a reduction in fertility. It should be mentioned that exposure to hypobaric chamber in simulated hypoxia differs from natural hypoxic conditions in the altitude where temperature and environmental radiation, among other factors, should be considered.

The physiological response to hypoxia, observed in the experimental groups as an abrupt increase in haematological variables (such as percentages of microhematocrit and reticulocytes) returning rapidly to the basal values (control), were expected as an adaptation to hypoxia (Bustos-Obregon \& Vargas, 2009 (CA))

As a result of the techniques applied in this study, it is possible to relate both morphological and physiological aspects of the spermatogenesis, assigning a direct effect on the structural changes of the testicular tissue and cellular DNA in the loss of fertile capacity (seminal quality) of the gametes.

The production of ROS, in response to the hypoxia and the lipoperoxidation of the cell membranes that its accumulation produces, has a proportionally direct relationship between the lesions produced by the hypoxia and the time or cycles of exposure. Consequently, in groups with the most number of cycles of exposure to hypoxia, an alteration of the spermatic variables was observed, determining increases in the Comet (+) test, which denotes 
a lesion at a nuclear or genetic level in the gametes causing DNA inestability (Hartley et al., 2009), which in addition, determines a reduction of the fertile potential.

Our immunohistochemical observations denoting increased expression of HIF-1 alpha, agrees with the increase in tubular and luminal diameter, epithelial vacuolization and the reduction in seminiferous epithelial height. All together, they explain the morphologic and morphometric alterations, which produce structural disruptions which in turn affect all the spermatogenic machinery and are related to the spermatic alterations mentioned beforehand. Similar testicular lesions were reported under chronic hypoxia (Bustos-Obregón et al., 2006); Farias et al., 2005; Farías et al., 2008; Gonzales et al., 2004; Cicutovik et al., 2009).

The immunolabeling of HIF-1 alpha seems to be a useful method to describe the evolution of spermatogenesis post IHH, in direct correlation with the oxygen sensory mechanisms with respect to its critical point. It should be mentioned that HIF-1 alpha increased expression results in activation of VEGF, thus promoting vascular proliferation. Moreover, this in turn, causes higher intrascrotal temperature ( $1.5^{\circ} \mathrm{C}$ above normal in the rat), which damages spermatogenesis (Farias et al, 2005), and increases ROS production and lipid peroxidation.

The expression of HSP-70 is, apparently, independent of this threshold and responds to multiple factors.

The alternant exposure to a hypoxic and a normoxic environment permits a certain recovery or attenuation of the general lesions caused during the hypoxia as it has been observed by Verrati et al., (2008) in alpinists. This contrasts with experimental models which consider a chronic exposure to hypoxia without alternation with normoxia, in which case the lesions are progressive and sustained (Garcia, 1977).

The mechanism of action involved in the testicular and spermatic lesions due to exposure to hypoxic environments is not clear. Nevertheless, considering the effective protection given by melatonin, a strong scavenging agent of free radicals, it is possible to propose that an excess of ROS, produced during hypoxia, plays a fundamental role in this process. It seems, therefore that the mechanism of ROS action should be explored in more detail in future works.

\section{CONCLUSIONS}

The sensitivity to hypoxia of populations of cells in active replication, added to the fact that the testicular tissue is already under a relative hypoxia (due to the difficulty of an adequate diffusion of oxygen to the adluminal compartment), makes of the seminiferous epithelium a candidate to suffer lesions by exposure to these environments. The lesions generated by IHH progressively increase, in relation to the number of cycles of exposure. Regarding the spermatic variable considered, there is an increase in Comet (+) test. Concerning the seminiferous tubule epithelium, an increase in HIF-1 alpha expression, in tubular and luminal diameter with vacuolization of the seminiferous epithelium and a reduction of its height are also apparent. Melatonin partially counteracts these lesions. The protective role shown by melatonin and its antioxidant characteristics, lead us to believe that ROS actively participates in producing such lesions, and consequently in reducing male fertility.

BUSTOS-OBREGÓN, E.; CASTRO-SÁNCHEZ; RAMOS-GONZÁLEZ, B. \& TORRES-DÍAZ, L. Daño de la espermatogénesis en rata en la hipoxia hipobárica intermitente y rol protector de la melatonina. II: Parámetros testiculares. Int. J. Morphol., 28(2):537$547,2010$.

RESUMEN: Actualmente no se conoce claramente si la fertilidad masculina se afecta por la hipoxia hipobarica intermitente (IHH). Esto es de importancia porque una gran población humana trabaja sobre 3000 metros sobre el nivel del mar (sml). Este trabajo analiza los cambios testiculares en ratas adultas Sprague Dawley luego de cinco ciclos de IHH (7 días a $4.200 \mathrm{sml}$ ) en una camara hipobarica/7días a 500 metros: Normoxia). Los animales de dividieron en grupos de 8; un grupo expuesto a hipoxia (7 días ) y los otros a IHH por uno y hasta cinco ciclos. Los controles $(500 \mathrm{sml}$ ) se analizaron al inicio y al final de los 70 días experimentales. Un set duplicado de ratas tratadas con melatonina (considerada protectora de la Hipoxia) se examinó también, asi como sus controles, inyectados con etanol $0,03 \%$ (solvente de la melatonina).Se realizó análisis histométrico e inmunohistoquímico del tejido testicular. El daño causado por IHH aumenta con el tiempo. La morfometría reveló un aumento de los diámetros del túbulo y lumen y una reducción de la altura del epitelio. La inmunohistoquímica de HIF-1 alpha muestra aumento del número de túbulos positivos con el tiempo aunque lo opuesto ocurre para HSP-70. El ensayo de cometa muestra un aumento del número de células espermátogénicas $(+)$. La melatonina controla este daño, posiblemente debido a asu alta eficiencia como neutralizador de especies reactivas del oxígeno. En conclusión, la exposición a IHH daña la función reproductiva masculina.

PALABRAS CLAVE: Espermatogénesis, Hipoxia Hipobárica Intermitente, Protección por melatonina. 
BUSTOS-OBREGÓN, E.; CASTRO-SÁNCHEZ; RAMOS-GONZÁLEZ, B. \& TORRES-DÍAZ, L. Rat spermatogenesis damage in intermittent hypobaric hypoxia and the protective role of melatonin. II: testicular parameters. Int. J. Morphol., 28(2):537-547, 2010.

\section{REFERENCES}

Agarwal, A. \& Said, T. Oxidative stress, DNA damage and apoptosis in male infertility: a clinical approach. Brit. $J$. Urol. Int., 95:503-507, 2005.

Anwar, M.; Mahfouz, H. A. \& Sayed, A. S. Potential protective effects of melatonin on bone marrow of rats exposed to cytotoxic drugs. Comp. Biochem. Physiol. AMol. Integr. Physiol., 119:493-501, 1998.

Awney, H.; Attih, A.; Habib, S. \& Mostafa, M. Effect of melatonin on the production of microsomal hydrogen peroxide and cytochrome $\mathrm{P}-450$ content in rat treated with aflatoxin B1. Toxicology, 172:143-8, 2002.

Behn, C.; Araneda, O.; Llanos, A.; Celedón, G. \& González, G. Hypoxia-related lipid peroxidation: Evidences, implications and approaches. Respiratory Physiology \& Neurobiology, 158:143-50, 2007.

Bailey, D. M.; Davies, B. \& Young, I. S. Intermittent hypoxic training: implications for lipid peroxidation induced by acute normoxic exercise in active men. Clin. Sci. (Lond) 101:465-75, 2001.

Bauche, F.; Fouchard, H. \& Jegou, B. Antioxidant system in rat testicular cells. FEBS Lett., 349:392-6, 1994.

Bhardwaj, A.; Verma, A.; Majumdar, S. \& Khanduja, K. Status of vitamin $\mathrm{E}$ and reduced glutathione in semen of oligozoospermic and azoospermic patients. Asian $J$. Androl., 2:225-8, 2000.

Bizarro, P.; Acevedo, S.; Niño-Cabrera, G.; Mussali-Galante, P.; Pasos, F.; Avila-Costa, M. \& Fortoul, T. Ultrastructural modifications in the mitochondrion of mouse Sertoli cells after inhalation of lead, cadmium or lead-cadmiummixture. Reprod. Toxicol., 17:561-6, 2003.

Bustos-Obregón, E . \& Celis, R. Efecto de la hipoxia en la reproducción de mamíferos. Función testicular postexposición en cámara hipobárica. En el Hombre y los Ecosistemas de Montaña (MAB-6). Montevideo, Ed. UNESCO-ROSTLAC, 1982. pp. 37-64.

Bustos-Obregón, E. \& Vargas, A. Ibuprofen and melatonin protects mouse testis in continuous or intermittent hypoxia. J. Androl. 30 (suppl): 89, 2009.

Bustos-Obregón, E.; Esveile, C.; Contreras, J.; Maurer, I. \& Sarabia, L. Effects of chronic simulated hypobaric hypoxia on mouse spermatogenesis. Int. J. Morphol. 24:481-8, 2006.

Cikutovic, M.; Fuentes, N. \& Bustos-Obregón, E. Effect of intermittent hypoxia on the reproduction of rats exposed to high altitude in the Chilean Altiplano. High Alt. Med. Biol., 10(4):357-63, 2009.

Check, D.; Graystone, J. \& Rowe, R. Hipoxia and malnutrition in newborrats: effects on RNA, DNA and protein in tissues. Am. J. Physiol., 217:642, 1969.

Chinn, K. \& Hannon, J. Effects of diet and altitude on the body composition of rats. J. Nutr., 100:732-8, 1970.

El-missiry, M. Prophylactic effect of melatonin on leadinduced inhibition of heme biosynthesis and deterioration of antioxidants systems in male rats. J. Biochem. Mol. Toxicol., 14:57-62, 2000.

El-sokkary, G.; Kamel, E. \& Reiter, R. Prophylactic effect of melatonin in reducing lead-induced neurotoxicity in the rat. Cell. Mol. Biol. Lett., 8:461-70, 2003.

Engel, S.; Schreiner, T. \& Petzoldt, R. Lipid peroxidation in human spermatozoa and maintenance of progressive sperm motility. Andrologia, 31:17-22, 1999.

Ercal, N.; Treeratphan, P.; Hammond, T.; Matthews, R.; Grannemann, N. \& Spitz, D. In vivo indices of oxidative stress in lead-exposed c57bl/6 mice are reduced by treatment with meso - 2, 3 - dimercaptosuccinic acid or N-acetylcysteine. Free Radic. Biol. Med., 21:157-61, 1996.

Farias, J.; Bustos-Obregón, E. \& Reyes, J. G. Increase in testicular temperature and vascularization induced by hypobaric hypoxia. J. Androl., 26(6):693-7, 2005.

Farias, J. G.; Bustos-Obregón, E.; Tapia, P. J.; Gutierrez, E.; Zepeda, A.; Juantok, C.; Cruz, G.; Soto, G.; Benites, J. \& Reyes, J. G. Time course of endocrine changes in the hypophysis-gonad axis induced by hypobaric hypoxia in male rats. The Journal of Reproduction and Development, 54:18-21, 2008.

Fornés, M. \& Bustos-Obregón., E. Study of nuclear decondensation of the rat spermatozoia by reducing epididymal transit. Andrologia, 26:87-92, 1994.

Galanis, A.; Pappa, A.; Giannakakis, A.; Lanitis, A.; Denarda, D. \& Sandaltzopoulos, R. Reactive oxygen species and HIF-1 signalling in cancer. Cancer Letters 266:12-2, 2008. 
Gamboa, R. Fisiología y fisiopatología cardiovascular durante la exposición aguda a la altura. Acta Andina 7:3546, 1998.

Garcia, M. A. Efecto de la expresion a una altura de 4.500 $m$ sobre la morfología y funcion testicular en ratas. XII Congreso Latinoamericano de ciencias Fisiológicas (México), 1977.

Garrido, N.; Mosaeguer, M.; Simon, C.; Pellicer, A. \& Remohi, J. Pro-oxidative and anti-oxidative imbalance in human semen and its relation with male fertility. Asian J. Androl., 6:59-65, 2004.

Golden A., Moline J., Bar-chama N. Male reproduction and environmental and occupational exposures: a review of epidemiologic methods. Salud Pública Mex., 41:93-105, 1999.

Gonzales, G.; Gasco, M.; Córdova, A.; Cheng, A.; Rubio, J. \&Villegas, L. Effect of Lepidium meyenii (Maca) on spermatogenesis in male rats acutely exposed to high altitude (4340 m). J. of Endocrinol., 180:87-95, 2004.

Hardeland, R. Antioxidative protection by melatonin: multiplicity of mechanisms from radical detoxification to radical avoidance. Endocrine, 27:119-30, 2005.

Hartley, R.; Castro-Sánchez, R.; Ramos-González, B. \& Bustos-Obregón, E. Rat spermatogenesis damage in intermittent hypobaric hypoxia and the protective role of melatonin. I Cauda epididimal spermatozoa. Int. J. Morphol., 27(4):1275-84, 2009.

Hemieda, F. Melatonin produced metabolic changes in testis and did not prevent indomethacin-induced testicular lipid peroxidation in adult rat. Indian J. Exp. Biol., 41:220-4, 2003.

Hiro-aki, Y. \& Hai-wang, T. Antagonistic effect of melatonin against cyanide-induced seizures and acute lethality in mice. Toxicol. Lett., 87:19-24, 1996.

Hsu, P..; Liu, M.; Hsu, C.; Chen, L. \& Guo Y. Lead exposure causes generation of reactive oxygen species and functional impairment in the rat sperm. Toxicology 122:133-43, 1997.

Kim. J. \& Han, S. Studies of hipoxia V. Effects of anoxia on developing connective tissue cells in rats. Anat. Rec., 165:531-41, 1969.

Kim, K.; Base, S.; Lee, O.; Bae, M.; Lee, M. \& Parck, B.
Insuline-like growth factor II induced by hypoxia my contribute to angiogenesis of human hepatocellular carcinoma. Cancer Res., 58:348-51,1998.

Koksal, I.; Usta, M.; Orhan, I.; Abbasoglu, S. \& Kadioglu, A. Potential role of reactive oxygen species on testicular pathology associated with infertility. Asian J. Androl., 5:95-99, 2003.

Lena, P. \& Subramanian, P. Evaluation of the antiperoxidative effects of melatonin in ammonium acetate-treated Wistar rats. Pol. J. Pharmacol., 55:10316, 2003.

Lodish, H.; Berk, A.; Matsudaira, P.; Kaiser, C.; Krieger, M.; Scott, M. \& Zipursky, S. Biología Celular y Molecular. $5^{\text {th }}$ ed. Medica Panamericana Press, Buenos Aires, Argentina, 2005.

Magalhaes, J.; Ascensão, A.; Soares, J. M.; Neuparth, M. J.; Ferreira, R.; Oliveira, J.; Amado, F. \& Duarte, J. A. Acute and severe hypobaric hypoxia-induced muscle oxidative stress in mice: the role of glutathion against oxidative damage. Eur. J. Appl. Physiol., 91:185-91, 2004a.

Magalhaes J, Ascensao A, Viscor G, Soares J, Oliveira J, Marques F, and Duarte J. Oxidative stress in humans during and after 4 hours of hypoxia at a simulated altitude of 5500 m. Aviat Space Environ Med., 75:16-22, 2004b.

Moller, P.; Loft, S.; Lundby, C. \& Olsen, N. V. Acute hypoxia and hypoxic exercise induce DNA strand breaks and oxidative DNA damage in humans. FASEB J., 15:11816, 2001.

Ostling, O. \& Johanson, K. Microelectroforetic study of radiation-induced DNA damage in individual cells. Biochem. Biophys Res. Vommon, 288:47-63, 1984.

Othman, A.; El-Missiry, M. \& Amer, M. The protective action of melatonin on indomethacin-induced gastric and testicular oxidative stress in rats. Redox Rep., 6:173-7, 2001.

Pande, M. \& Flora, S. Lead induced oxidative damage and its response to combined administration of a-lipoic acid and succimers in rats. Toxicology, 177:187-96, 2002.

Ping-Chi, H.; Ming-Yie, L.; Chao-Chin, H.; Lih-yuh. C. \& Yueliang, L. Effects of vitamin $\mathrm{E}$ and/or $\mathrm{C}$ on reactive oxygen species-related lead toxicity in the rat sperm. Toxicology, 128:169-79, 1998. 
Radak, Z.; Lee, K.; Choi, W.; Sunoo, S.; Kizaki, T.; OhIshi, S.; Suzuki, K.; Taniguchi, N.; Ohno, H. \& Asano, K. Oxidative stress induced by intermitten exposure at a simulated altitude of $4000 \mathrm{~m}$ decreases mitochondrial superoxide dismutase content in soleus muscle of rats. Eur. J. Appl. Physiol. Occup. Physiol., 69:392-5, 1994.

Reiter, R. J.; Tan, D. X.; Manchester, L. C. \& Qi, W. Biochemical reactivity of melatonin with reactive oxygen and nitrogen species: a review of the evidence. Cell Biochem. Biophys, 34:237-56 2001.

Reiter, R. J.; Tan, D. X.;Mayo, J. C.; Sainz, R. M.; Leon, L. \& Czarnocki, Z. Melatonin as an antioxidant: biochemical mechanisms and pathophysiological implications in humans. Acta Biochim. Pol., 50(4): 112946, 2003.

Reiter, R. J.; Tan, M. D. \& Maldonado. Melatonin as an antioxidant: physiology versus pharmacology, J. Pineal Res., 39(2):215-6, 2005.

Samali, A. \& Cotter, T. Heat shock proteins increase resistance to apoptosis. Exp. Cell Res., 223:163-70, 1996.

Sarada, S. K. S.; Dipti, P.; Anju, B.; Pauline, T.; Kain, A. K.; Sairam, M.; Sharma, S. K.; Ilavazhgan, G.; Devendra K. \& Selvamurthy, W. Antioxidant effect of beta-carotene on hypoxia induced oxidative stress in male albino rats. J. Ethnopharmacol., 79:149-53, 2002.

Siqués, P. \& Brito, J. Trabajo a gran altura intermitente: Nueva situación epidemiológica. Universidad Arturo Prat Press, Iquique, Chile, 2001.

Sobarzo, C. \& Bustos-Obregón, E. Acute effect of parathion of the seminiferous epithelium of immature mice. Rev. Chil. Anat., 18:61-8, 2000.

Tan, D. X.; Manchester, L. C.; Sainz, R. M.; Mayo, J. C.; Alvarez, F. \& Reiter, R. J. Antioxidant strategies in protection against neurodegenerative disorders. Expert Opin. Ther. Patents., 13:1513-43, 2003.

Tejada, R.; Cameron, J.; Norman, A.; Marik, J. \& Friedman $\mathrm{S}$. A test the practical evaluation of male infertility by acridine orange (AO) fluorescence. Fertility and Sterility. 42:88-91, 1984.

Verratti, V.; Berardinelli, F.; Di Giulio, C.; Bosco, G.; Cacchio, M.; Pellicciotta, M.; Nicolai, M.; Martinotti S. \& Tenaglia Raffaele. Evidence that chronic hypoxia cau- ses reversible impairment on male fertility. Asian J. of andrology, 10(4):602-6, 2008.

Vijayalaxmi, Reiter, R. J.; Herman, T. S. \& Meltz, M. Melatonin reduces gamma radiation-induced primary DNA damage in human blood lymphocytes. Mutat. Res. 397:203-8, 1998.

Whittington, K.; Harrison, S.; Williams, K.; Day, J.; Mclaughlin, E.; Hull, M. \& Ford, C. Reactive Oxygen Species (ROS) production and the outcome of diagnostic test of sperm function. Int. J. Androl., 22:236-42,1999.

\section{Correspondenceto: \\ Eduardo Bustos-Obregón \\ Universidad de Chile \\ Facultad de Medicina \\ Independencia 1027 \\ Santiago 7, Chile \\ (POBox 70061)}

Phone 56-2-9786473

Fax 56-2-7237488

Email: ebustos@med.uchile.cl

Received: 03-01-2010

Accepted: 09-04-2010 
